\title{
Vulnerability of Antarctic shelf biodiversity to predicted regional warming
}

\author{
David K. A. Barnes*, Lloyd S. Peck
}

British Antarctic Survey, Natural Environment Research Council, High Cross, Madingley Road, Cambridge CB3 0ET, UK

\begin{abstract}
Predictions of sensitivity to climate change of polar benthos vary markedly depending on whether physiological or ecological/biodiversity criteria are considered. A realistic consensus view must be achieved as soon as possible. Having been very cool and constant for several million years, polar hotspots such as the Antarctic Peninsula (AP) are now rapidly warming. The current rate of $\mathrm{CO}_{2}$ increase and, with a lag phase, temperature, is unparalleled-maybe for 10s of millions of years. Experimental evidence suggests the shallow mega- and macrobenthos is very sensitive to temperature change (stenothermal). Being warmed to about $10^{\circ} \mathrm{C}$ kills most species tested to date but even smaller experimental rises (just 2 or $3^{\circ} \mathrm{C}$ above normal) drastically hinders their ability to perform critical functions, such as predator avoidance behaviour. In contrast, new evidence of bathymetric and geographic distributions shows species ranges encompass localities with varying and warmer temperatures such as the intertidal zone or the shelf of South Georgia. This suggests, at the species level, an unexpected ability to live in areas with significantly different and raised temperature regimes. Scientists have focused on potential responses of a few species in a few areas. However, these are often atypical of fauna on the whole. Distribution assessments suffer from not knowing the capacity differences between populations and how fast they arise. To begin meaningful estimates of how shelf mega- and macrobenthos will respond to rapid warming, where and at what should we be looking? The AP continental shelf is probably amongst the most sensitive. A more widespread evaluation of the capabilities of different species and across lifehistory cycles is needed. We need to compare differences between communities in the more temperature-variable and -stable sites to predict ecological scale responses to future changes.
\end{abstract}

KEY WORDS: Ecology · Physiology $\cdot$ Polar ectotherm $\cdot$ Climate change $\cdot$ Acclimation $\cdot$ Macrobenthos Distribution · Temperature limit

\section{INTRODUCTION}

The western Antarctic Peninsula (WAP) is one of the most rapidly changing ecosystems on the planet and an area of rich biodiversity, most of which has been described to lie on the continental shelf (Clarke \& Johnston 2003). How will this rich and largely endemic fauna respond to current and predicted regional warming? There are 2 main approaches that have been used to analyse potential responses, physiological and ecological, and these have a marked schism in the predicted outcomes. Physiological experiments over the last few decades have suggested some marine ectotherms may be sensitive to even small increases in temperature, but some ecological information on distributions contrasts with such an assessment. With rates of global climate change accelerating, bridging the gap between these approaches and moving the field towards a realistic understanding of likely ecosystem responses is the focus of this manuscript.

In the last decade we have gathered an unparalleled quantity and quality of information about past environmental change. Examination of gas bubbles and oxygen isotopes in ice cores from a variety of sites in Greenland and Antarctica have revealed the details of some atmospheric changes throughout the last and previous 7 glacial cycles (EPICA 2004). Comparison of trends of $\mathrm{CO}_{2}$, other drivers and temperature in ice cores have now given us a good picture of climate change in the past 800 thousand years (800 kyr) and, thus, the context for current change. Even recently (in the last interglacial period) our planet has been 
warmer than at present, and $\mathrm{CO}_{2}, \mathrm{CH}_{4}$ (methane) and surface temperature have all changed rapidly before, but we are now in a time of dramatic change unlike any for which we have a detailed record (EPICA 2004). Levels of atmospheric $\mathrm{CO}_{2}$ are now higher than at any point during the last $800 \mathrm{kyr}$, and are rising rapidly. Raupach et al. (2007) reported that the rate of global $\mathrm{CO}_{2}$ emissions has tripled from $1.1 \% \mathrm{yr}^{-1}$ in the last decade to $>3 \% \mathrm{yr}^{-1}$ in the current decade. Historic records show that 21 of the hottest $22 \mathrm{yr}$ (air temperatures) on record have been since 1980 and the 4 hottest years have all been in the last decade. This warming is unevenly distributed, with the most intensively warming areas concentrated around parts of the 2 polar regions (Hansen et al. 2006). The WAP is one of the localities showing the most rapidly warming air temperatures (King et al. 2003). Recently it was detected that a significant increase in sea temperatures has been building up in the Bellingshausen Sea over the last 50 yr (Meredith \& King 2005). The decrease in the extent of arctic sea ice is regularly discussed with concern by the scientific and popular media, but the duration and extent of seasonal sea ice to the west of the Antarctic Peninsula (AP) has substantially decreased, with less acclaim (Zwally et al. 2002). Along the AP both the number of glaciers in retreat and the rate at which they are retreating have increased (Cook et al. 2005). Rapid rises in $\mathrm{CO}_{2}$ and temperature, and the physical responses to these, such as glacial retreat, surface freshening, ocean acidification, amongst others, have a drastic potential to influence life on earth. The earth's system is, therefore, in a period of change unprecedented in recent geological time, and the AP is possibly the fastest changing site on the planet. It is in such places that we should look first to identify the changes in and responses of the species, communities and ecosystems living there.

Although some changes over decades have been noted in both pelagic (Atkinson et al. 2004) and benthic (Barnes et al. 2006a) populations of the Southern Ocean, whether these are linked to regional warming is currently uncertain. There has been a marked response of life to elevated temperatures in the terrestrial environment of the AP (Walther et al. 2002). The high thermal capacity of water means that the physical rates of change in the sea are different. In addition, Antarctic marine animals differ considerably in their physiology, longevity, growth rates and many other aspects to the few types that live on land (Arntz et al. 1994, Peck et al. 2006). Amongst the traits that characterise Antarctic marine animals is that they may be amongst the most sensitive of any large region on earth to predicted climate change (Peck 2005, Clarke et al. 2007). In the current paper we concentrate on the marine environment around Antarctica about which we know most, i.e. the continental shelf (0 to $1000 \mathrm{~m})$. We calculate, using a variety of sources (satellite imagery, aerial photo mosaics, swath bathymetry, existing bathymetric maps and estimates of grounding lines of ice-sheets), that the continental shelf around Antarctica covers about $4376000 \mathrm{~km}^{2}$ and that about $34 \%$ of the shelf currently lies under ice (Fig. 1). New areas of the continental shelf are emerging from parts of ice shelves, such as the Filchner and Larsen, which have collapsed, but ice shelves cyclically grow and their outer margins disintegrate. In the last few decades the Ross Ice Shelf has grown, so, despite the recent collapse of various ice shelves elsewhere around Antarctica, we calculate the net emergence of continental shelf from under ice sheets to be only approximate to $1 \%$ of Antarctica's total continental shelf area, but if the Ross Ice Shelf entered a cycle of regression this could be altered markedly. Recent scientific cruises have provided new insight into life on areas of the continental shelf that were, but are no longer, under ice shelves. Drilling through ice shelves has revealed life and even colonisation histories in the dark underneath (e.g. Post et al. 2007). Despite this, virtually all of what we know about physical conditions and life on the Antarctic shelf is from the $65 \%$ that is not covered by ice shelves, and it is this region that we concentrate on in the current study.

For several million years the temperatures in the Southern Ocean, which is inside the Polar Front ( $\mathrm{PF}$; the strongest jet of the Antarctic Circumpolar Current), have been cold and relatively constant (Zachos et al. 2001). Sea surface temperatures typically vary just a few degrees throughout the entire year and include some of the most thermally stable places on the surface of the planet (Clarke 1988). Because of the high latitudes the light climate is extremely seasonal and, as a direct result, so is primary productivity and food availability for animals (e.g. see Clarke 1988). Although regularly influenced by catastrophic iceberg impacts at depths shallower than $250 \mathrm{~m}$ (Gutt et al. 1996), the Antarctic continental shelf has an abundant and rich benthos (Arntz et al. 1994, Clarke \& Johnston 2003). Antarctica has around $2.6 \%$ of the world's coastline (although $>50 \%$ of this is ice bound) and $~ 8 \%$ of the world's continental shelf. Surprisingly, Antarctica has $>8 \%$ of the world's species in many major groups (Fig. 2), and many of these occur nowhere else (are endemic, see Arntz et al. 1997). Antarctica's continental shelf is the only large continental shelf region where non-indigenous species (NIS) have yet to be found to be established (but see Lewis et al. 2003) and is almost certainly the least anthropogenically influenced. The 3 main ways that organisms can respond to changes such as regional warming are through physiological flexibility (including behavioural modifica- 


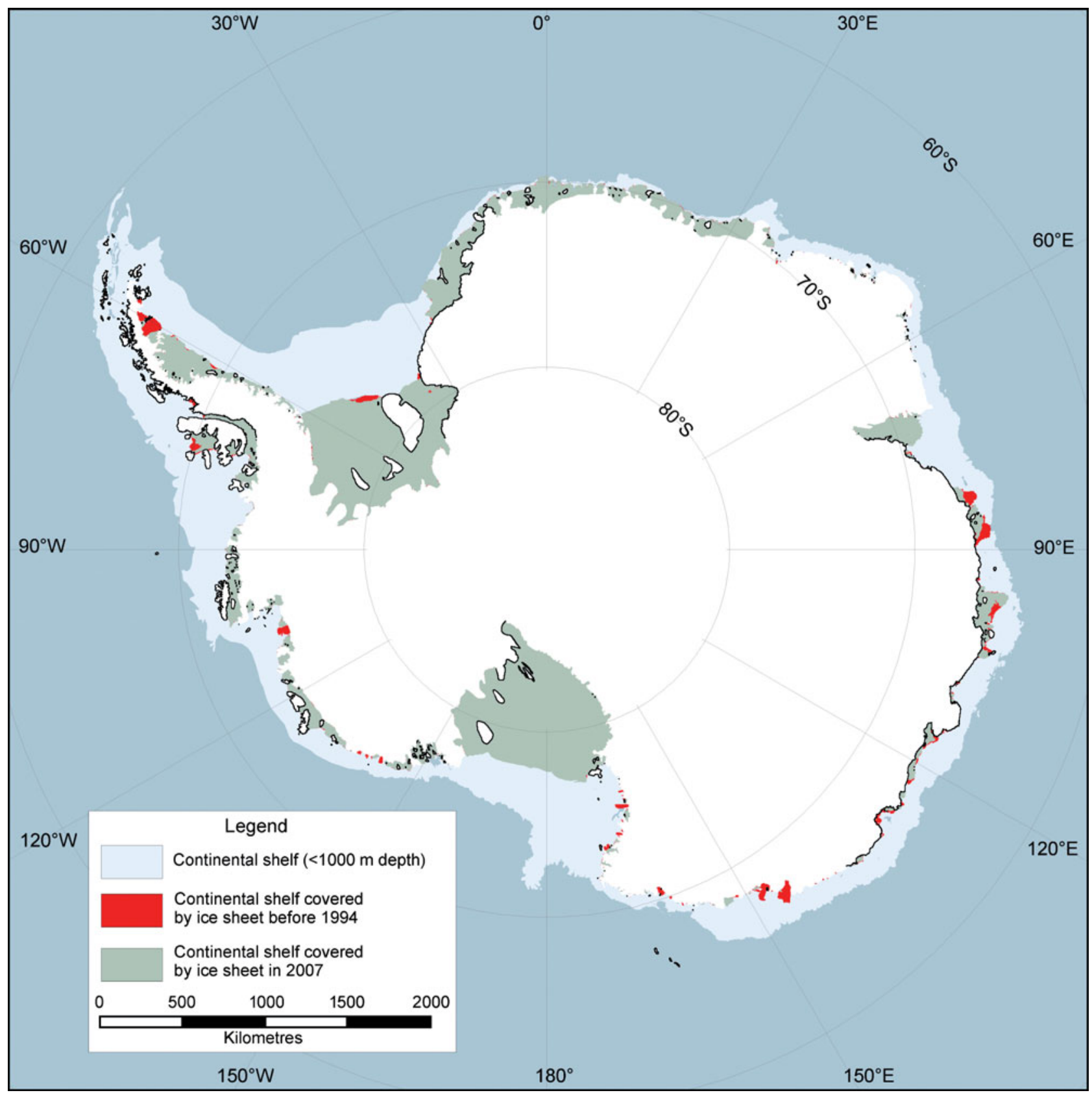

Fig. 1. The Southern Ocean continental shelf surrounding Antarctica: areas without an overlying ice sheet (pale blue), areas that have recently emerged from the ice sheet following collapses (red) and areas still under the ice sheet (green)

tions), evolving, or migrating, but it has been suggested that Antarctic benthos have unusually poor capacities to do any of these and thus could be on the brink of catastrophic change (Peck 2005). There is, however, a fourth potential organism response, and that is extinction (Clarke 1987).

The present article focuses on just one aspect of climate change, the direct effects of raised temperature on the mega- and macrobenthos living on Antarctica's continental shelf. We suggest that both the location and the taxa investigated are amongst the most appropriate, as the AP is amongst the most rapidly warming place on earth and the vast majority of known Antarctic species are marine and occur here. The currently dominant paradigm from laboratory experiments exposing these animals to raised temperatures is that they are amongst the most stenothermal on earth (Somero \& DeVries 1967) and are, therefore, very vulnerable to direct warming (Peck et al. 2004). This contrasts with data on faunal distributions, showing spe- 


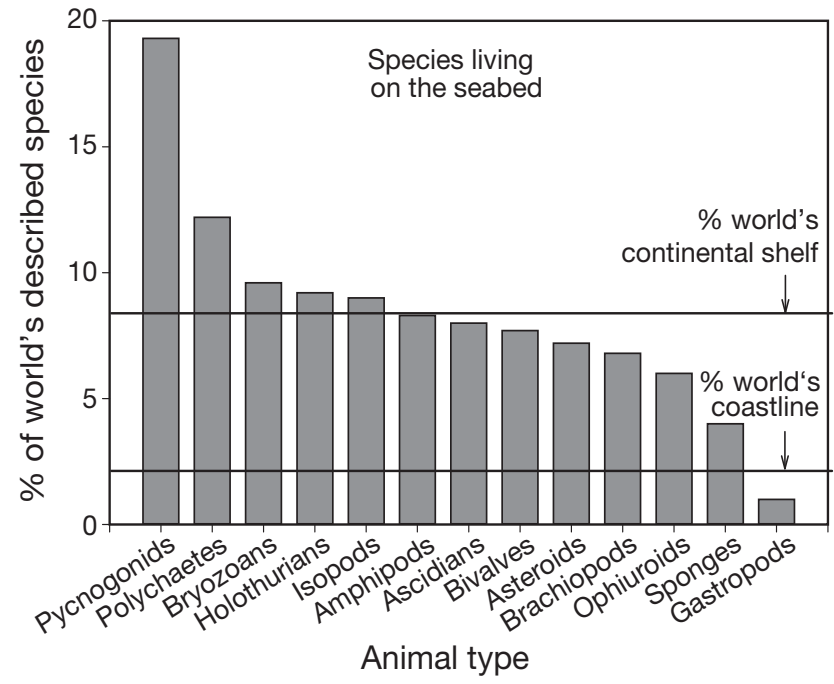

Fig. 2. Proportion of total number of global species present in the Southern Ocean for several major animal groups. Data from Clarke \& Johnston (2003) updated using data by Linse et al. (2006), Barnes \& Griffiths (2008) and Munilla (2008). Horizontal lines: proportions of global coastline and shelf area for the Southern Ocean

cies to inhabit a wide range of sites with markedly different temperature regimes. There is currently a clear contradiction in the predictions of faunal vulnerability from these 2 sources that needs to be addressed. In the present paper we consider various sources of evidence to determine, firstly, how robust Antarctic shelf megaand macrobenthos are to predicted regional warming and, secondly, what experiments or observations on which animals should we be making to get a better understanding, faster.

\section{ANTARCTIC SHELF BENTHOS AND BIODIVERSITY}

The animals living on the Antarctic continental shelf are unusual in many ways. They live in the coldest, most oceanographically stable (compared to large parts of the planet that undergo water current changes or even reversals, such as during El Niño), seasonally intense and (certainly in the top few $100 \mathrm{~m}$ ) naturally disturbed conditions, but the taxa, populations and communities also have other striking features. The cold and well-mixed water on the Antarctic shelf carries very high levels of oxygen, allowing some arthropods, notably some amphipods, isopods and pycnogona (sea spiders) to become relative giants (Chapelle \& Peck 1999). In contrast, other groups, notably some of the molluscs, are typically very small $(<10 \mathrm{~mm}$; see Hain 1990). The constraints here remain obscure. Antarctic invertebrates tend to use very little oxygen, that is, their metabolic rates are very low. Experimental measurements of oxygen consumption have now been carried out on shallow-dwelling bivalve and gastropod molluscs, a brachiopod, bryozoans, a nemertean, an echinoid, an asteroid, isopods, ascidians and spongesmany are amongst the lowest values of oxygen use for any invertebrate (about 20 to $500 \mu \mathrm{g} \mathrm{O}_{2} \mathrm{~g}^{-1}$ ash-free dry mass $\mathrm{h}^{-1}$; see Barnes \& Peck 2005). Using so little energy may be a long-term adaptation either to low temperature or to an environment in which food is in short supply for much of each year. The macro- and megafauna is dominated by sessile suspension feeders (Arntz et al. 1994, 1997), and the appearance to an observer is of a very still environment with little obvious movement. Even some of the predators, such as pycnogona, echinoderms, or nudibranch molluscs, have been observed as moving little more than a meter in a week (authors' pers. obs.). Compared to any other shelf environment there are very few durophagus predators around Antarctica (Aronson et al. 2007). Overall, there is clearly an unusual balance of feeding strategies, but Antarctic benthos also show strong differences in reproduction, growth and other processes compared with benthos elsewhere.

Although several large common shallow species are broadcast spawners, the overall balance between planktotrophic and lecithotrophic (feeding or nonfeeding) larvae is unclear. For example, the large infaunal bivalve mollusc Laternula elliptica releases eggs and sperm into the water column, and fertilisation is external. However, development continues within the egg capsule through to a stage competent for settlement, and embryos/larvae have been cultured within the egg capsule for up to 18 mo (Peck et al. 2007a). Pearse et al. (1991) showed that most polar echinoderms produce lecithotrophic larvae and use only reserves supplied with the egg (they are independent of primary production by phytoplankton). Poulin et al. (2002) further suggested that, whilst the number of polar echinoids with planktotrophic larvae have declined, those which brood have radiated. Reproduction and other processes are generally lengthier in polar waters. An egg development period of 24 mo appears widespread compared with 12 mo or less in temperate species, and this has been demonstrated in the starfish (Odontaster validus), the ophiuroid (Ophionotus victoriae), the sea urchin (Sterechinus neumayeri), the infaunal bivalve (L. elliptica), the limpet (Nacella concinna), the brachiopod (Liothyrella uva) and the octocoral (Ainigmaptilon antarcticum) (Orejas et al. 2002, Brockington et al. 2006 and references therein). There are a few exceptions, and the scallop (Adamussium colbecki) matures its eggs in 1 season (Tyler et al. 2003), as do some amphipod species (Clarke 1988), but the latter are still slow compared to temperate amphipods. Antarctic benthos live in the 
slow lane, such that to see that a predator (e.g. a nemertean worm) has chased its prey (e.g. limpet) or that a bivalve has reburied if dug up, requires timelapse photography. Activities such as burrowing, crawling, walking, or drilling in predators are conducted at rates that range from half to a tenth of those in temperate species (Fig. 3; Harper \& Peck 2003, Peck et al. 2004). Larval development times are very slow (Bosch et al. 1987), including those in brooding species (Peck et al. 2007b), and growth of adults, though spanning a wide range, has long been thought slow (Arntz et al. 1994). New research directly comparing species from polar, temperate and tropical regions has confirmed earlier studies using less direct comparisons that growth at very high latitudes is an order of magnitude slower (Clarke et al. 2004, Heilmayer et al. 2004, Barnes et al. 2007). Some evidence suggests that some Antarctic suspension feeders may grow at comparable rates to lower latitude species when they are actually feeding and growing; they appear slow overall because they spend less time doing this (Clarke 1988, Barnes 1995). However, it seems that at least part of a general explanation for slow growth in Antarctic invertebrates may be due to very slow rates of protein synthesis and elevated rates of protein degradation (Fraser et al. 2007). As well as growing slowly, Antarctic benthos can reach a great age compared to like-with-like shelf taxa elsewhere. Some sponges and seastars may grow for 100 yr or more (Pearse 1969, Dayton 1989), bivalves, brachiopods and echinoids may live half a century (e.g. Brey 1991, Peck \& Bullough 1993).

Some groups are unusually abundant in the shallows compared to lower latitudes, such as the Pycnogona and Brachiopoda, whilst others are conspicuously absent or near absent, such as the marine reptiles, reptant decapods (crabs), balanomorph barnacles and cartilaginous fish. Antarctic invertebrates may reach remarkable abundances on the shelf. Despite being relatively large in size, echinoids (sea urchins) have been reported in areas 100s of square metres in many localities around Antarctica (see Arntz et al. 1994). The same is true for some of the most common ophiuroids, asteroids and holothurians, whilst smaller bivalves and polychaetes (amongst others) may reach densities sev-
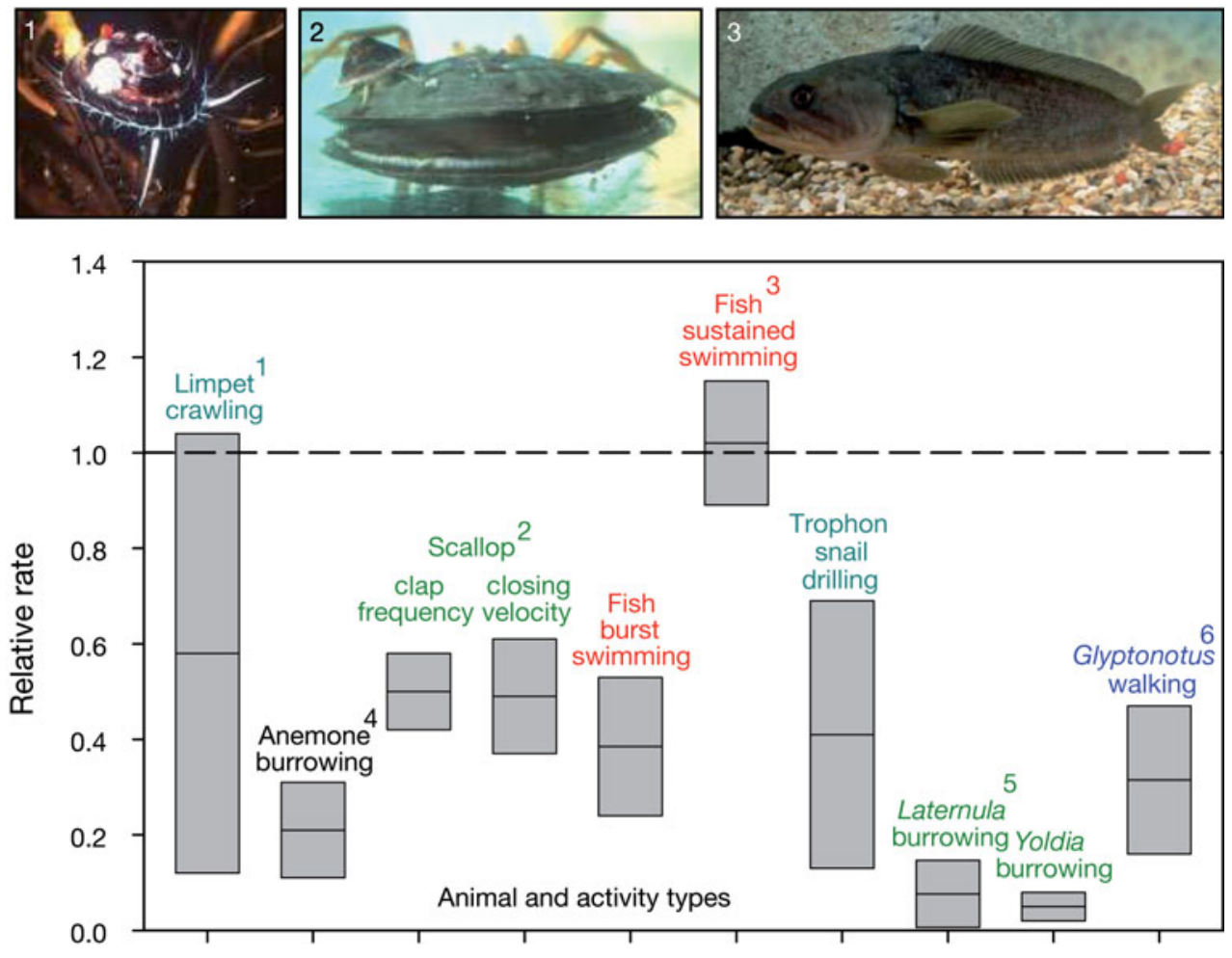

Fig. 3. Rates of conducting various activities for a range of Antarctic marine invertebrates and fish compared with related or ecologically similar temperate species. Values for temperate species are set at 1 (horizontal dashed line). Boxes are means (solid horizontal line) \pm SD. Figure modified from Peck et al. (2006), with data added for isopod walking from Young et al. (2006)
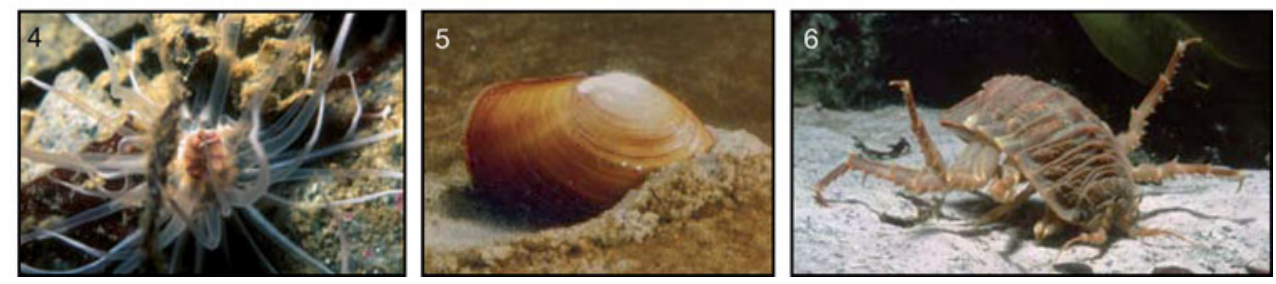
eral orders of magnitude higher than this (Peck \& Bullough 1993). Other than where ice has recently been scoured, sampling has revealed very high richness and diversity, as well as abundance. Even the sampling of relatively small areas has revealed very high richness in terms of numbers of species and other taxonomic (to phylum) levels (e.g. Sahade et al. 1998, Gambi et al. 2000). Many other studies around Antarctica have simila-rly reported very high local richness levels (compared to arctic, most temperate and even some tropical localities) across a variety of scales and at a variety of shelf depths (see Arntz et al. 1994), showing the continental shelf is rich at local as well as at regional spatial scales and at phylum through to species taxonomic levels. Relative to coastline length or shelf area, the Southern Ocean is rich (more so than would be expected if a richness to shelf area relationship were linear, but this is unlikely) (Clarke \& Johnston 2003). This richness has added importance as most groups have such high endemism (Arntz et al. 1997). That is, loss of species from the Southern Ocean (compared to any other locations) is more likely to be a loss of global biodiversity. The Southern Ocean encompasses a wide area and, unsurprisingly, the richness and endemism within the Southern Ocean vary considerably from place to another. Some regions, such as the Weddell Sea, tend to be rich across many groups; other areas, such as the Ross Sea, are very rich in some, but not in other, taxa (see Arntz et al. 1994, Linse et al. 2006, Barnes \& Griffiths 2008). Regions can also sharply contrast in the levels of endemism, such that a hotspot of richness might not be a hotspot of endemism or one of high regional endemism might not be rich in overall Antarctic endemics. Finally, the Southern Ocean shelf also shows some very strong contrasts between areas in which the benthos have been as intensively studied as around European coasts (e.g. around King George Island) and others that are amongst the least studied shelf areas on the planet, such as the Amundsen Sea, where seabed areas of $>1000 \mathrm{~km}^{2}$ have had no samples taken from them.

During the last decade scientific attention on Antarctic benthos has increasingly moved to focus on the sensitivities of the shelf fauna to the accelerating 'threat' of climate change. The main and most immediate effects seem to be slowing of the thermohaline circulation in the deep sea (Kaiser \& Barnes 2008, this Special), acidification, regional warming, and disturbance by NIS invasion, iceloading, sedimentation and freshening on the shelf (see Barnes \& Conlan 2007, Clarke et al. 2007). In this paper, we concentrate on temperature, as it is the best understood, and it arguably poses the most serious threat in general. For groups with calcareous skeletons, though, acidity also poses a major issue. As $\mathrm{CO}_{2}$ dissolves in water to increase $\mathrm{H}^{+}$ions (and thus acidity), drastic rises in atmospheric partial pressures of $\mathrm{CO}_{2}$ over the last century have increased ocean acidity. Seas are projected to increase more in acidity in the 300 yr since 1900 than over the last 24 million years (Turley et al. 2007). One of the main problems to organisms is that a more acid solution increases $\mathrm{CaCO}_{3}$ (calcium carbonate) solubility, which they precipitate to make skeletons and shells. Amongst the first and most seriously affected biota have been those in the Southern Ocean, as saturation levels of $\mathrm{CaCO}_{3}$ are naturally lowest there, particularly of the aragonite form (cf. calcite form). With increasing acidity the carbonate compensation depth (CCD) horizon, which is shallow in the Southern Ocean will become even shallower, and the ability of many shelled animals to synthesise and, particularly, to maintain $\mathrm{CaCO}_{3}$ will decrease (Orr et al. 2005). Many organisms have calcite skeletons or shells, and, of these, those with exposed skeletons, such as corals, serpulid polychaetes and bryozoans, are most at risk of these dissolving in a future, more acidic Southern Ocean. However, molluscs, such as gastropods and bivalves, partially or wholly use aragonite for shells. Thinning of shells poses particular problems on the shelf because of the intense and frequent mechanical disturbance there (Barnes \& Conlan 2007). There will also be interactions with other factors, such as warming and arrival of NIS. The cold is considered a key barrier to a Southern Ocean invasion of crushing (durophagus) predators, such as crabs, so combined warming and acidification could lead to rapid depletion of thin-shelled (and mainly sedentary or sessile) prey by the arrival of new predators (Aronson et al. 2007). It is not clear at present how a more acidic ocean will affect different groups. Species that have open $\mathrm{CaCO}_{3}$ skeletons could suffer due to dissolution of skeletons. Species with soft tissue covering skeletons (e.g. echinoderms, fish and squid) will face a greater energetic cost to deposit skeleton and maintain concentration gradients. It is not clear how species with skeletons separated from seawater by a covering, such as molluscs with periostracum, will be affected. Early development stages are often cited as being the most sensitive to environmental insult. There are few studies on the effects of lowered $\mathrm{pH}$ on embryonic and larval development, and, of those studies, results that consider the changes predicted for the next 50 to $100 \mathrm{yr}$ are even more scarce. However, some of those have shown significant detrimental effects in some species (S. Dupont et al. unpubl.). Antarctic marine macrobenthos are potentially more vulnerable in this respect because of their extremely extended development periods (Bosch et al. 1987, Peck et al. 2007a).

However, as on land, most attention has been geared towards direct response to temperature change (see Walther et al. 2002, Peck 2005). Antarctica has a poor 
fossil record and Antarctic invertebrates have very low turnover rates, so studying adaptation through evolution as a solution is problematical despite the fact that this may be important for 2 reasons. First, the Southern Ocean is very deep and well mixed, and, thus, the amount of energy required to heat it up to physiologically significant temperatures is higher than in shelf areas elsewhere. Using a population genetics model, Lynch \& Lande (1993) suggested evolution might keep pace with moderate sea temperature change. Second, Antarctic animals may live to and reproduce at great age. A variety of research results have shown that older animals produce proportionately more mutations (Drake et al. 1998, Nevo 1998), and this may provide some evolutionary compensation for their slow turnover rate. However, physiological studies suggest large, reproductive individuals are poorer at coping with change (Peck et al. 2007b). Organisms can migrate to escape regional warming; along North American and European coasts this may be/have been the dominant organism response both in the present and past (e.g. Valentine \& Jablonski 1991, Southward et al. 2004). The scope to do this around Antarctica has been argued to be low, because only a few degrees of latitude are covered and there is very little linear (north to south) coastline (Peck 2005, Clarke et al. 2007). In contrast, it could be argued that nowhere else on the planet can animals migrate geographically from an area rapidly changing (e.g. AP) to an area that, to date, appears to have exhibited little or no change (around East Antarctica). Furthermore, because of unusually high levels of eurybathy, Antarctic shelf animals have a greater (than elsewhere) scope for bathymetric migration to cooler water (Brey et al. 1996). Conversely, species with narrow bathymetric ranges, restricted to either the shallow or deeper shelf areas, may be at more risk to rapid change. The ability of Antarctic organisms to solve the problems posed by regional warming by either evolution or migration is not clear cut, but, as most experimentation has focussed on the third possible escape, physiological flexibility, so will we. The crucial context to this, though, is what level of variability in sea temperature has been normal in the past and present and what temperature changes in terms of both maximum values reached and rates of change are likely to occur in the next decades and centuries.

\section{OCEANOGRAPHY AND REGIONAL WARMING}

Averaged across the continent of Antarctica, air temperatures have risen by about $0.6^{\circ} \mathrm{C}$ in a century, but the mean for WAP aerial warming is $>6$ times this value (King et al. 2003). Even a mean for the WAP hides a much stronger signal of winter than summer warming and a gradient of intensity increasing from south to north (King et al. 2003). How important is this to life in Antarctica? On land, the size and duration of ice-free habitats increases and conditions in these change for both existing populations and for new propagules arriving (see Walther et al. 2002). However, not only is the land a relative desert with few species or types of animals present, but those which are there may face $>20^{\circ} \mathrm{C}$ daily temperature changes and even greater annual variation (Peck et al. 2006). The vast majority of Antarctic species live on the Southern Ocean continental shelf, at much more constant temperatures (than on land), both at evolutionary and ecological time scales. We know most about the temperatures of the shallow surface waters, as measurement with remotely sensed (satellite) imagery is relatively easy, as are direct spot measurements using CTD probes. Antarctic shelf benthos live in several water masses at any 1 place, dependent on depth. Antarctic surface water (AASW) forms the top $\sim 50 \mathrm{~m}$, is cold $\left(-1.8^{\circ} \mathrm{C}\right)$ in winter and only a few degrees warmer in summer. Immediately below this is winter water (WW) that extends to a depth of $\sim 200 \mathrm{~m}$, which is near freezing, but is warmer with depth. However, the water mass that most Antarctic shelf benthos inhabit is below those mentioned above and is typically much more stable in temperature. At least in the WAP, it is occasionally flooded by warmer deep water (Fahrbach et al. 1992). On the WAP, deep shelf water is normally (modified upper) circumpolar deep water (CDW), and, thus, benthos there typically live at temperatures of $\sim 1.5^{\circ} \mathrm{C}$, but this can vary even locally.

At the present time, shelf benthos living in the top $\sim 100 \mathrm{~m}$ of the continental shelf seabed typically experience $\sim 3^{\circ} \mathrm{C}$ annual temperature changes, but this varies geographically (Fig. 4a). At typical shelf depths, the temperature regime differs from that at the surface and is more stable, but also differs geographically (Fig. 4b). Even within a region (e.g. Wilkins Ice Shelf, WAP) CTD casts taken within days and 10s of kilometres of each other show seabed $(\sim 500 \mathrm{~m})$ temperatures varying across $-1.6,-1.2,-0.8,-0.2,+0.7,+1.18$ and $+1.42^{\circ} \mathrm{C}$ (D. Shoosmith pers. comm.). These variations are still small compared to those experienced by temperate species, but they are highly significant in relation to data from laboratory experiments on temperature tolerance limits for polar species. Despite such temporal, geographic and bathymetric variability, distinct warming signals have been detected in the Southern Ocean. A number of studies have reported slight warming of Weddell deep water (WDW) over the last half a century (see Smedsrud 2005 and references therein). Much more significant levels of warming were reported by Meredith \& King (2005) west of the 

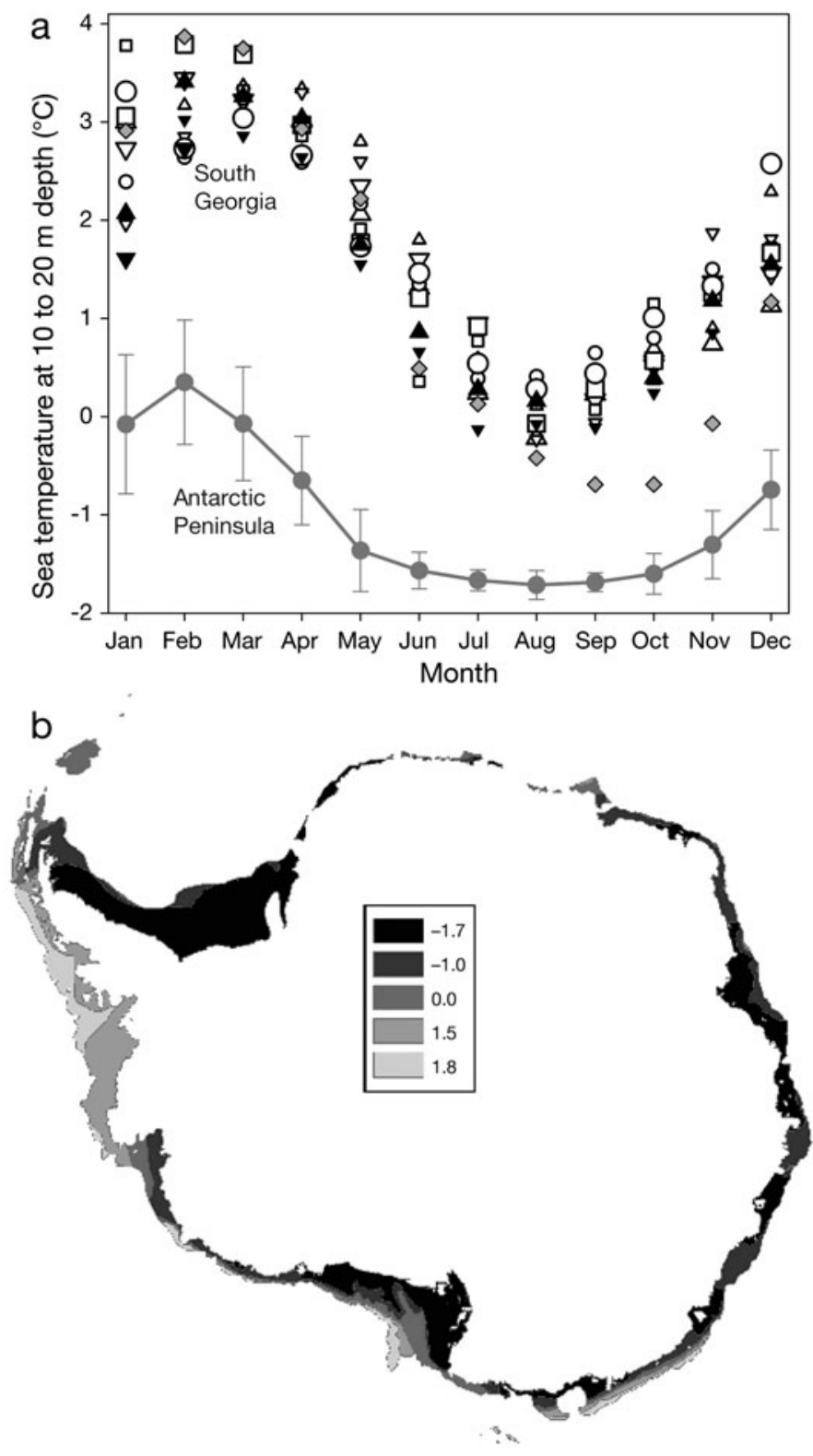

Fig. 4. Sea temperature variability in (a) the shallows and (b) at $400 \mathrm{~m}$. Data in (a) are from Ryder Bay, Antarctic Peninsula, which is fairly typical for Antarctic shallows, and from South Georgia, one of the more extreme localities in the Southern Ocean (for South Georgia, different symbols represent different years between 1972-2003); source: Barnes et al. (2006). Temperatures in (b) are shown in ${ }^{\circ} \mathrm{C}_{i}$ source: www.nodc. noaa.gov/OC5/WOA05/pr_woa05.html

$\mathrm{AP}$, showing $\mathrm{a}>1^{\circ} \mathrm{C}$ rise during this time, but only in the shallows. This only influences surface water masses, and, by $100 \mathrm{~m}$ depth, the signal of this warming is lost. Because of the complexity of regional warming, the poor ability of models to reproduce warming to date and in the past, and the complexity of Southern Ocean circulation, predictions of warming in the
Southern Ocean are vague and have large errors associated with them. Murphy \& Mitchell's (1995) model suggested a rise in the realm of $2^{\circ} \mathrm{C}$, but with confidence intervals of also about $2^{\circ} \mathrm{C}$. More recently, Clarke et al. (2007) suggest that near surface sea temperatures might rise 1 to $2^{\circ} \mathrm{C}$, following the rises reported by Meredith \& King (2005), but make it clear that this is merely 'an educated guess'. So far, both $\mathrm{CO}_{2}$ and temperature have generally increased faster than typical predictions and seem to be accelerating, so current estimates may prove to be conservative (Raupach et al. 2007).

Present day $\mathrm{CO}_{2}$ increase and warming is clearly very rapid, more so than any event in the last $800 \mathrm{kyr}$, and maybe even in the last 30 million years. However, even since the Southern Ocean cooled to its current level of cool temperatures there have been both rises to warmer temperatures than now and a number of rapid thermal increases. Various sources of evidence suggest that some of these events have strongly influenced the Southern Ocean. For example, 3 million years ago, in the middle Pliocene, it became warmer than it is today and there was a period of rapid ocean warming, in some places (though not in the Southern Ocean) by as much as $8^{\circ} \mathrm{C}$ (Alley 2000). Much more recently, just 7 to 9 kyr ago the Antarctica Peninsula became warmer (than today) and some current ice shelves were absent (see Bentley et al. 2005). As well as long-term cycles (such as Milankovitch related) in climate and temperature, there have been past periods of change, some of which were considerable, but none appear as rapid as those expected within the next century. Other than changes in the diatom composition in marine sediments, we have little evidence of how Southern Ocean organisms responded to past changes. How shelf benthos will respond to current and predicted changes is currently theorised on the basis of short-term (acute to monthly scale acclimation) physiological experiments and ecological observations.

\section{EVIDENCE OF SHELF BIOTA TEMPERATURE SENSITIVITY}

Experiments to evaluate tolerances to temperature change have now been carried out using a variety of animal types from the Southern Ocean nearshore environment. The results of these have led to the consideration that Antarctic marine species are highly stenothermal, compared to species outside the Southern Ocean, with the vast majority having experimental upper lethal temperatures in experiments below or near $10^{\circ} \mathrm{C}$ (Somero \& DeVries 1967, Peck 2005). The most stenothermal species recognised so far, the brachiopod Liothyrella uva and the bivalve mollusc 
Limopsis marionensis, can only survive in a temperature window between -2 and $+5^{\circ} \mathrm{C}$, when temperatures are raised by around $1.5^{\circ} \mathrm{C} \mathrm{wk}^{-1}$ (Peck 1989). The physiological mechanisms identified as setting the short-term temperature tolerance limits, at least in marine ectotherms, are associated with failures in oxygen supply to tissues and with reductions in whole animal aerobic scope (Pörtner et al. 1998). Recently, Pörtner (2002) elucidated the physiological basis of temperature limits at different levels of organisation within the individual, and showed a hierarchy of tolerance from the molecular through cellular and tissue to the whole animal. Thus, the tightest limits are set at the whole animal level, and there are progressively wider tolerances at each step along the physiological hierarchy.

Possibly the main factor implicated in explaining reduced aerobic scope, and the concomitant poor temperature tolerance in Antarctic marine ectotherms, is the role of mitochondria in the metabolic response to temperature change (Pörtner 2002). Mitochondria are reported to be unable to compensate their function for reduced temperature (Johnston et al. 1998). Critical temperatures for physiological survival are reached when aerobic scope reaches zero and mitochondria in tissues transfer to anaerobic metabolism. In the red muscles of Antarctic fish mitochondrial densities are increased in Antarctic species to allow activity to proceed at comparable rates (Johnston et al. 1998). This adjustment of mitochondrial density has been argued as being critical in defining and shifting thermal tolerance windows (Pörtner 2002). However, the data are sparse, but, in the few assessments of invertebrates, no such increase appears in the mitochondrial density for species evolved to low temperature (S. Morley \& G. Lurman pers. comm.). If this is the normal condition then other mechanisms (leading to an oxygen supply deficit) - such as symmorphosis producing limited temperature tolerances in species inhabiting highly stable environments - would be needed. The processes evident in animal response to rising temperature, in acute to medium-term physiological experiments, are a progressive reduction in aerobic scope to a point where it is lost completely and mitochondria in tissues transfer to anaerobic metabolism, the critical physiological limit of Pörtner et al. (1998). Beyond this point, survival is dictated by organismal tolerance to the build up of toxic anaerobic end products of metabolism. This tolerance may allow some species to survive weeks or months in suboptimal conditions and then recover when temperatures and oxygen availability allow.

Recently, it has been argued that the important criteria for a population or species to survive in a given area are not, however, dictated directly by its physiological tolerance limits, but by ecophysiological constraints on its capacity to perform critical biological functions such as feeding, locomotion and reproduction. Investigations of activity in Antarctic molluscs have indicated that activity is surprisingly sensitive to temperature change. Temperature limits for performing activity are significantly lower than whole animal upper lethal temperatures. This progressive decline in capability is consistent with declining aerobic scope (Peck et al. 2004). The large infaunal bivalve mollusc Laternula elliptica has an upper lethal temperature in experiments of around $9^{\circ} \mathrm{C}$. It transfers to anaerobic metabolism (its critical physiological limit) at around 5 to $6^{\circ} \mathrm{C}$ (Peck 2005). However, no individuals are able to rebury after removal from sediment at $5^{\circ} \mathrm{C}$, and $50 \%$ of the population fail at temperatures of 2 to $3^{\circ} \mathrm{C}$ (Peck et al. 2004). These figures are all raised by elevating ambient oxygen levels and decreased by lowering ambient oxygen (Peck et al. 2007b). The limpet Nacella concinna is similar in that its upper lethal temperature is $9.5^{\circ} \mathrm{C}$ (Peck 1989), but $50 \%$ of the population loses the ability to right themselves when turned over at 2 to $3^{\circ} \mathrm{C}$, and the scallop Adamussium colbecki dies at 5 to $6^{\circ} \mathrm{C}$, but loses the capacity to swim between 1 and $2^{\circ} \mathrm{C}$. Burrowing, righting and swimming are all major activities that involve extensive muscular activity, and at least the recovery from the activity is dependent on aerobic scope. Very recently studies on the starfish Odontaster validus have shown that it can maintain activity to much higher temperatures than the molluscs previously studied (Peck et al. 2008). It continued to be able right itself when turned over to $8^{\circ} \mathrm{C}$. Interestingly, its upper temperature to continue feeding was close to this at $7^{\circ} \mathrm{C}$. Thus, in this species, the limit for activity was close to the limit for feeding. There is a clear need for more information of this type.

Across species and latitudes, aerobic scopes decline in ectotherms with declining temperature, such that Antarctic marine species have some of the most restricted scopes of any fauna. It is clear that in studies where temperatures are raised acutely (at around $0.5^{\circ} \mathrm{C} \mathrm{d}^{-1}$ or faster) or more moderately (e.g. 1 to $3^{\circ} \mathrm{C}$ $\mathrm{wk}^{-1}$ ), the oxygen limitation and the loss of aerobic scope are key factors in whole animal failure. Recently, studies on several species of Antarctic fish have reported the capacity to acclimate and function for several weeks to months at temperatures around $4{ }^{\circ} \mathrm{C}$ (Gonzalez-Cabrera et al. 1995, Lowe \& Davison 2005, Podrabsky \& Somero 2006). Invertebrates, however, appear less able to acclimate to elevated temperatures, as attempts to acclimate animals to $3^{\circ} \mathrm{C}$ have failed for the scallop Adamussium colbecki (D. Bailey pers. comm.), for the clam Laternula elliptica (S. Morley pers. comm.) and the brittle star Ophioniotus victoriae (Clark et al. unpubl. data). One invertebrate species, 
the starfish Odontaster validus, has been acclimated to higher temperatures, having survived several weeks at $6^{\circ} \mathrm{C}$, and completing a full Specific Dynamic Action (SDA) cycle following feeding at this temperature (Peck et al. 2008).

There appears, therefore, to be a trend of decreasing maximum survival temperature with reduced rate of warming, with acute survival temperatures higher than those for medium-term warming, which are, in turn, higher than acclimation and limits for critical biological functions or activity. From this we would predict that population survival temperatures would be even lower than those for acclimated animals, on the basis that some ecologically important functions will be lost because of extra homeostatic costs at the acclimation temperature, unless other processes, such as genetic adaptation, can produce solutions to the challenge within the timescales required. In the absence of genetic modification we would predict that warming of sea temperatures to values only as high as $2^{\circ} \mathrm{C}$ above current maxima could pose significant long-term survival barriers for some populations of shallow shelf species. Deeper shelf species, which are virtually unrepresented in physiological experiments and live in greater long-term thermal constancy, are possibly much less able to adapt to rapid changes in temperature regimes. Despite the apparent strength and commonality in measured responses of Antarctic ectotherms to experimental warming, interpretations of such studies and some ecological evidence contrast strongly.

\section{EVIDENCE OF SHELF BIOTA ROBUSTNESS TO TEMPERATURE}

Much of the above evidence for the Southern Ocean benthos being highly stenothermal, and as such sensitive to small increases in temperature, has been based on ecologically short-term and evolutionarily minute timescale laboratory acclimations (e.g. Somero \& DeVries 1967, Peck et al. 2004). Whilst the data from such experiments seem strong, and clearly show this fauna to be more sensitive than those from temperate latitudes, the question arises as to whether the level of sensitivity they exhibit will make them vulnerable to the coming environmental change. Firstly, the experiments themselves have only shown that benthos cannot acclimate at the rapid rates (hours, days and weeks) of temperature rise in which they have so far been manipulated. The rates of rise used were all environmentally unrealistic, and thus vulnerability may be exaggerated (Seebacher et al. 2005). Secondly, no attempt has been made to maintain benthos in seasonally changing but raised temperatures, i.e. attempting simulation of real conditions. Current observations suggest raised summer temperatures and shorter periods of winter minimum temperature are a likely outcome of regional warming in the near future (Meredith \& King 2005). Third, although many of the functional activities examined are a measure of extra energy costs to animals and multiple costs have not been studied, they may not be as relevant to survival prospects as measuring costs associated with feeding or gonad maturation. For example, it may not be particularly important if a limpet cannot 'right' itself if turned over or a bivalve rebury as it may be very rare that such an attribute is needed. (However, it appears other characteristics such as tenacity in limpets may also decrease with rising temperature; Morley unpubl. data.) Fourth, the specific species tested could be considered atypical of their groups and of Antarctic benthos in general, as virtually all tested invertebrates have been shallow broadcaster spawners. An ecological argument for robustness of the Antarctic shelf benthos is the spatial variability of present conditions. There are a number of natural situations where Antarctic benthos live in conditions of raised temperatures compared to those typical of the Southern Ocean shelf and experimental physiology 'baselines'. This might not seem surprising, as temperate species have populations that live in markedly different environmental regimes across their latitudinal distributions, and higher latitude populations have lower temperature thresholds than those at lower latitudes. It should be noted though that present distributions are the product of (evolutionary) processes not strictly relevant to today's change, or physiological experiments. Also, wide geographic spread likely involves some local adaptation, thus, within each area a species could be stenotypic, despite the species across areas being eurytypic. However, evaluations of sensitivity in Antarctic species are limited to shallow water cold sites, and extrapolating these directly to other populations may produce inaccuracies. There is clearly a need for evaluations of population sensitivity to environmental change in populations across latitudes and depths, and at sites with differing temperature regimes. There is also a need to identify if there is seasonal acclimation of temperature sensitivity, as seen in temperate zone species, and to assess how rapidly populations can adapt to differing conditions in Antarctica. All such evaluations are currently absent.

The geographic range of many Antarctic species (including many endemics) extends to many locations, e.g. King George Island or South Georgia, with raised summer (and even warmer winter) temperatures than elsewhere in the Southern Ocean. At South Georgia, for example, there are substantial populations of many of the species shown in experiments at higher latitudes 
to be vulnerable to small temperature rises (e.g. Laternula elliptica and Nacella concinna) living at $3^{\circ} \mathrm{C}$ above typical summer and $2{ }^{\circ} \mathrm{C}$ above typical winter temperatures for higher latitude Antarctic shallows. It seems likely that when the population genetics are compared between locations that these populations will be separate at some level (e.g. in N. concinna; Beaumont \& Wei 1991). Although a number of studies have attempted to assess the genetics of populations of Antarctic marine fauna in space, in most studies the sample sizes per site/depth have been $<20$ and thus insufficient for meaningful population genetics (but sufficient to investigate, e.g., cryptic speciation; see Held \& Waegele 2005). Some species have larvae with the potential to travel considerable distances, and the population level differences in these species may be small. However, they are clearly large enough to produce recognisable phenotypic differences. More than elsewhere, distributions of Antarctic benthos are not just geographic, they are unusually eurybathic (Brey et al. 1996); thus, many should be more capable of migrating to and surviving at depth. The wide depth span of many species means that even at 1 geographic location the range of temperatures across depths may be significant (see e.g. Holeton et al. 2005). Shortly after the 1967 to 1970 eruptions at Deception Island, Gallardo et al. (1977) reported a progression of species returning to the caldera, despite being patchily very warm and chemically altered.

Laboratory experiments have shown that a wide range of Antarctic marine invertebrates can survive several days of temperature elevations to well in excess of $10^{\circ} \mathrm{C}$ in trials raising temperatures by $1^{\circ} \mathrm{C} \mathrm{d}$ (L. S. Peck, M. Clark \& S. Morley unpubl. data). These include bivalve molluscs, amphipods, cnidarians, holothurians, urchins, brittle stars, starfish, limpets and brachiopods. The timescales and durations of exposure of field populations of these species to warm conditions is crucial here, and there is urgent need for observations of how long individuals spend at higher temperatures and what the effects are. Without such clarification, observations like these are of limited value.

Even more extreme temperatures (and other conditions) are experienced by marine species, which occur in the intertidal zone. Waller et al. (2006) showed that contrary to the paradigm of this being denuded and just home to a few transient species, 40 or more species were common and resident but cryptic. They reported an $18^{\circ} \mathrm{C}$ range in temperatures in just $6 \mathrm{~h}$ of $1 \mathrm{~d}$ in their study area of the intertidal zone. These temperature changes are far in excess of any used in laboratory experiments to assess temperature limits. This poses an interesting problem in that laboratory experiments change temperatures at what are claimed environmentally unrealistic rates, but the large number of intertidal species can clearly survive well in far more variable conditions than those studied in the laboratory. However, few believe that if sea temperatures in Antarctica rose by $18^{\circ} \mathrm{C}$ in $6 \mathrm{~h}$ and did not return to close to $0^{\circ} \mathrm{C}$ in a few hours that any species would survive long term. However, none of the species reported by Waller et al. (2006) were intertidal specialists, indeed all of them were common shelf species. Surprisingly, the list of species included most of those 'model' species thought to be highly stenothermal. However, as for the observations from Deception Island, without data on timescales of exposure and biological status of the individual organisms involved, such observations can only be viewed as pointing the way towards the need for further data and clarification. There is an urgent need for such detailed observations and monitoring of environmental conditions. Other factors also need evaluation, such as whether the organisms living in extreme thermal locations, such as the intertidal zone or Deception Is., are self-recruiting or able to survive in these conditions only as outliers of a deeper metapopulation. More than most oceans or seas, the Southern Ocean has a distinct fauna, demarked by the PF, but regions within it are not very distinct. Even the benthos at the outer margins close to the PF, e.g. Heard Island, comprise 'normal' Southern Ocean genera and species (see e.g. Linse et al. 2006, Barnes \& Griffiths 2008). Yet the PF has wandered considerably south of the shelf at such locations in evolutionary time, flooding the benthos with considerably warmer (cool temperate) waters (Barron 1996). However, we cannot be certain as to the depth of which historic intrusions happened, and, for example, we do not know how diatoms (indicators of past water movement) were advected before reaching the seabed. Conversely, the PF has also wandered north beyond the so-called 'sub-Antarctic' archipelagos of Prince Edward, Crozet, Kerguelen and Macquarie. The shelf around these islands now contains many species otherwise known only from the Southern Ocean (see e.g. Linse et al. 2006, Barnes \& Griffiths 2008, Munilla 2008). PF migration is not just a feature occurring on evolutionary time scales; Moore et al. (1999) plotted the minimum and maximum extents of the PF over $13 \mathrm{yr}$ and showed that it varied in a linear (north to south) direction by several $100 \mathrm{~km}$ over shelf areas. It would seem that at least much of the benthos living within a few $100 \mathrm{~km}$ of the $\mathrm{PF}$, irrespective of whether they are south or north of it, can cope with either Antarctic or cool temperate conditions over ecological or evolutionary periods of time. Here, we need to identify sites where the wandering of the PF has changed temperatures for benthic populations by several degrees over short periods of time (months or a few 
years) and evaluate differences from communities at more temperature-stable sites, and also to measure their tolerances to elevated temperature.

Some species occurring in the Southern Ocean are also found further north than the PF or sub-Antarctic archipelagos and thus tolerate an even greater range of sea temperatures. Although species-level endemism is clearly high in the Southern Ocean (Arntz et al. 1997, Clarke \& Johnston 2003), new data show this may have been overestimated, at least in some taxa. The most recent and comprehensive studies of a number of very different taxa have shown that species endemism levels are $<60 \%$ rather than the $\sim 80 \%$ assumed just a few years ago (Fig. 5). This suggests 2 important points with respect to potential vulnerability. First, the PF is sufficiently porous to gene flow in some groups in ecological and evolutionary time that, although there are no data testing the relatedness of populations of the same species on either side of the divide, it is possible that southern temperate populations have not significantly separated from their populations in the Antarctic. Secondly, the minimum sea temperatures at most southern temperate shelves (where $>40 \%$ of Antarctic species also occur) exceed the maximum on shelves in the Southern Ocean (see Barnes \& Conlan 2007, their Fig. 8). This suggests that a significant proportion of the Antarctic benthos is either capable of adapting to the temperature changes seen in the past or previous raised temperatures would have led to a loss of populations rather than of species. Populations and species do not exist in isolation, and thus, for a realistic approach to likely influences, a community level approach is needed. Quantifying differences in capabili-

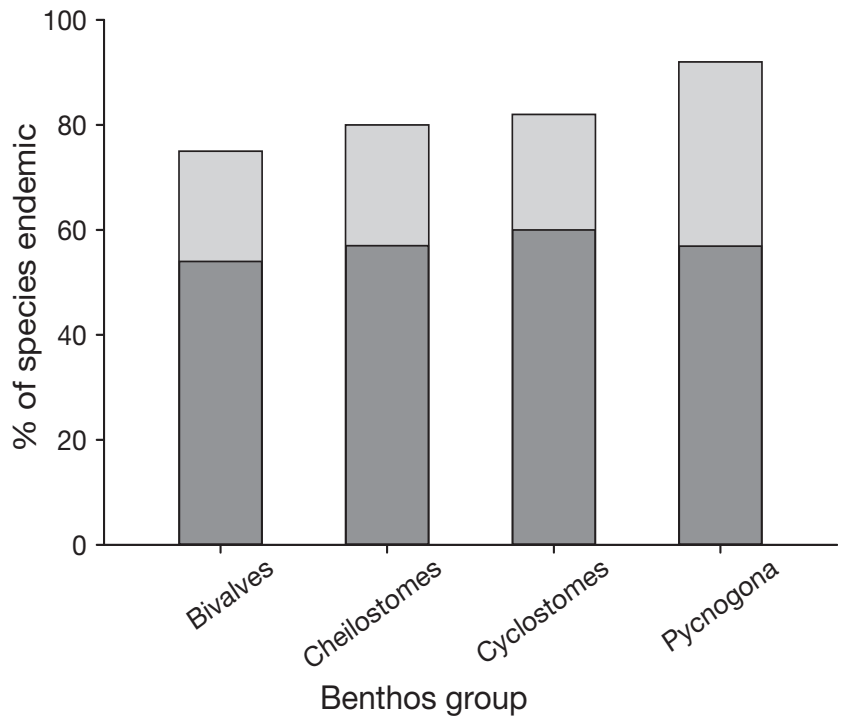

Fig. 5. Changes in estimated endemism levels in selected taxa in the Southern Ocean. Light grey: estimates from a decade ago (Arntz et al. 1997); dark grey: estimates from recent data (Linse et al. 2006, Barnes \& Griffiths 2008, Munilla 2008) ties between geographically isolated populations and how rapidly these can arise is imperative. Assessments of the effects of change on competitive interactions, life histories, predator/prey interactions and energy/carbon utilisation and flow are all needed for a wide range of sites across the sub-Antarctic through the maritimeAntarctic to high-Antarctic sites. Our knowledge base is currently woefully poor in the data needed to predict ecological responses to change.

It is clear there is a mismatch between extremes of interpretations of physiological and ecological observations to date. At the moment, evidence of fragility or robustness are both lacking various important contexts and are drawn from very small portions of the rich marine biodiversity around Antarctica. Of most importance now is to assess current physiological and ecological evidence together and determine what experiments or observations need to be made or taken to gain a much better insight into the vulnerability of Southern Ocean shelf biodiversity.

\section{CONCLUSIONS}

The shelf around Antarctica includes some of the least known surface regions of our planet. Despite this, sampling to date already makes the fauna there richer than would be expected for its area. Perhaps of even more note is that most species are endemic to the Southern Ocean or small regions within it, and this is the least anthropogenically altered shelf on earth. In a time of acute rapid regional warming, there is a very strong need for research into areas of study that would now markedly improve our understanding of organismal resistance to climate warming and enhance our ability to predict species likelihood of failure or survival. The AP is arguably the best place on the planet for this, as the most intense warming is concentrated there and in the Arctic. As opposed to the Arctic, the conditions in the AP have historically been much more stable and the fauna evolved in situ are thus likely to be more sensitive. Many experiments to date have shown an inability of model Antarctic ectotherms to acclimate to even small rises in sea temperature and that even $2^{\circ} \mathrm{C}$ could critically hinder biological functions. Ecological interpretations of the same data and observations of populations of the same species already living at raised temperatures conflict with suggested immediate vulnerability. It is very likely that some species will be extremely vulnerable to predicted climate change, that others will be highly robust to it and that many will lie between these extremes.

What we need to know is 'if' the response of Antarctic ectotherms follows a normal curve, how flat the curve is, and which animals represent the extremes 
and why. Whether the current suggested vulnerability of the few model animals tested to date is ecologically meaningful can be investigated by longer term temperature rises superimposed on simulated seasonal temperatures. Oxygen limitation is clearly important in acute warming, but if Antarctic marine ectotherms are maintained at elevated temperatures for long periods of a year or more will they then acclimate to the point where reproductive output and competitive abilities are similar to animals in current normal temperatures, or will performance be permanently reduced?

Other important advances in physiological work will be to broaden the range of model animals, in terms of life strategy and trophic level as much as taxonomic identity. Of great interest will be how much the trends in broadcast spawners are reflected in those with more typical Antarctic characters, such as lecithotrophy and brooding - it may be that these are actually more sensitive to change. Experiments are already underway to test (arguably more) ecologically meaningful responses of biological functions, such as arm regeneration in ophiuroids, to raised temperatures. There is also a need to understand how multiple costs and stressors affect temperature limits. Thus, how do factors such as feeding, temperature stress, activity and defence against oxygen-free radical damage interact and affect temperature limits? A crucial ecological context will be how much linkage there is between populations of the same model species currently living at different temperatures with bathymetry and geography. For example, an obvious experiment would be to compare the relatedness and tolerance of one of the current model species at South Georgia, King George Island and a high Antarctic locality (i.e. 3 differing temperature regimes within the Southern Ocean). Ideally, this would be investigated in both Antarctic endemics and species that occur north of the $\mathrm{PF}$, as their responses are likely to differ. As Clarke et al. (2007) point out, there is a dearth of information on marine (but not terrestrial, see Walther et al. [2002]) community level information on the influences of regional warming. Examinations of marine community level responses are not going to be easy to carry out, but this is an obviously huge gap in current knowledge and work. We urgently need to catch up with the knowledge of this type that has been gathered for terrestrial species. Effects of change on life-history characters, on larval development, on recruitment, growth, age at first reproduction, reproductive effort, competitive interactions, predator/prey relationships, abundance, production:biomass $(P / B)$ ratios and much more need evaluation from a range of sites with differing ecologies. Data of this type are essential for realistic predictions of the effects of change. Without them we will be restricted to attempting to make physiological data more relevant ecologically and more predictive.
With a tripling of atmospheric $\mathrm{CO}_{2}$ levels in the last decade (Raupach et al. 2007), such a strong link between past $\mathrm{CO}_{2}$ levels and temperature (EPICA 2004) and the AP being one of the most acute centres of warming (King et al. 2003), we should expect temperatures to rise as or more severely than predicted. Despite encompassing large areas, which are some of the least well sampled ecosystems on the planet, the fauna we have already found makes the Southern Ocean anomalously rich and endemic. If its fauna is highly sensitive, then it could be the most important early warning system for dramatic changes in marine ecosystems as the climate changes. Detecting and understanding biotic changes will be crucial, and, coupled with the current dichotomy of suggested potential responses, should lead scientists to seek explanations for such variation and close the gap between ecological and physiological evaluations to realistic estimates. Solving these problems in the polar regions is of global significance because, although these issues have arisen here first, they will also be critical in dictating the failure or persistence in populations and species globally. It seems that we should approach gauging the likely response of the Southern Ocean's vast, rich and least interfered with fauna with some sense of urgency.

Acknowledgements. The authors thank Peter Fretwell for help in constructing Fig. 1, and Prof. Andrew Clarke, Dr. Julian Gutt and 2 anonymous referees for comments leading to an improved manuscript.

\section{LITERATURE CITED}

Alley RB (2000) Ice-core evidence of abrupt climate changes. Proc Natl Acad Sci USA 97:1331-1334

Arntz WE, Brey T, Gallardo VA (1994) Antarctic zoobenthos. Oceanogr Mar Biol Annu Rev 32:241-304

Arntz WE, Gutt J, Klages M (1997) Antarctic marine biodiversity: an overview. In: Battaglia B (ed) Antarctic communities: species, structure and survival. Cambridge University Press, Cambridge, p 3-14

Aronson RB, Thatje S, Clarke A, Peck LS, Blake DB, Wilga CD, Seibel BA (2007) Climate change and invisibility of the Antarctic benthos. Annu Rev Ecol Evol Syst 38: $129-154$

Atkinson A, Siegel V, Pakhomov EA, Rothery P (2004) Longterm decline in krill stock and increase in salps within the Southern Ocean. Nature 432:100-103

Barnes DKA (1995) Seasonal and annual growth in erect species of Antarctic bryozoans. J Exp Mar Biol Ecol 188: 181-198

Barnes DKA, Conlan KE (2007) Disturbance, colonization and development of Antarctic benthic communities. Philos Trans R Soc Lond B Biol Sci 362:11-38

Barnes DKA, Griffiths HG (2008) Biodiversity and biogeography of southern temperate and polar bryozoans. Glob Ecol Biogeogr 17:84-99

Barnes DKA, Peck LS (2005) Extremes of metabolic strategy in Antarctic Bryozoa. Mar Biol 147:979-988

Barnes DKA, Webb K, Linse K (2006a) Slow growth of Antarc- 
tic bryozoans increases over 20 years and is anomalously high in 2003. Mar Ecol Prog Ser 314:187-195

Barnes DKA, Fuentes V, Clarke A, Schloss IR, Wallace MI (2006b) Spatial and temporal variation in shallow seawater temperatures around Antarctica. Deep-Sea Res II 53:853-865

Barnes DKA, Webb K, Linse K (2007) Growth rate and its variability in erect Antarctic bryozoans. Polar Biol 30: 1069-1081

Barron JA (1996) Diatom constraints on the position of the Antarctic Polar Front in the middle part of the Pliocene. Mar Micropaleontol 27:195-213

Beaumont AR, Wei JHC (1991) Morphological and genetic variation in the Antarctic limpet Nacella concinna (Strebel, 1908). J Molluscan Stud 57:443-450

Bentley MJ, Hodgson DA, Sugden DE, Roberts SJ and others (2005) Early Holocene retreat of the George VI Ice Shelf, Antarctic Peninsula. Geology 33:173-176

Bosch I, Beauchamp KA, Steele ME, Pearse JS (1987) Development, metamorphosis and seasonal abundance of embryos and larvae of the Antarctic sea urchin Sterechinus neumayeri. Biol Bull 173:126-135

Brey T (1991) Population dynamics of Sterechinus antarcticus (Echinodermata: Echinoidea) on the Weddell Sea shelf and slope, Antarctica. Antarct Sci 5:253-266

Brey T, Dahm C, Gorny M, Klages M, Stiller M, Arntz WE (1996) Do Antarctic benthic invertebrates show an extended level of eurybathy? Antarct Sci 8:3-6

Brockington S, Peck LS, Tyler PA (2006) Gametogenesis and gonad mass cycles in the Antarctic echinoid Sterechinus neumayeri. Polar Biol 17:465-468

> Chapelle G, Peck LS (1999) Polar gigantism dictated by oxygen availability. Nature 399:114-115

Clarke A (1987) The adaptation of aquatic animals to low temperatures. In: Grout BWW, Moris GJ (eds) The effects of low temperature on biological systems. Edward Arnold, London, p 15-34

Clarke A (1988) Seasonality in the Antarctic marine environment. Comp Biochem Physiol B 90:461-473

Clarke A, Johnston NM (2003) Antarctic marine benthic diversity. Oceanogr Mar Biol Annu Rev 41:47-114

Clarke A, Aronson RB, Crame JA, Gili JM, Blake DB (2004) Evolution and diversity of the benthic fauna of the Southern Ocean continental shelf. Antarct Sci 16:559-568

> Clarke A, Murphy EJ, Meredith MP, King JC, Peck LS, Barnes DKA, Smith RC (2007) Climate change and the marine ecosystem of the western Antarctic Peninsula. Philos Trans R Soc Lond B Biol Sci 362:149-166

Cook AJ, Fox AJ, Vaughan DG, Ferrigno JG (2005) Retreating glacier fronts on the Antarctic Peninsula over the past half-century. Science 308:541-544

Dayton PK (1989) Interdecadal variation in an Antarctic sponge and it's predators from oceanographic climate shifts. Science 245:1484-1486

> Drake JW, Charlesworth B, Charlesworth D, Crow JF (1998) Rates of spontaneous mutation. Genetics 148:1667-1686

EPICA (European Project for Ice Coring in Antarctica) (2004) Eight glacial cycles from an Antarctic ice core. Nature 429:623-628

Fahrbach E, Rohardt G, Krause G (1992) The Antarctic coastal current in the southeastern Weddell Sea. Polar Biol 12: 171-182

Fraser KPP, Clarke A, Peck LS (2007) Growth in the slow lane: protein metabolism in the Antarctic limpet Nacella concinna (Strebel, 1908). J Exp Biol 210: 2691-2699

Gallardo VA, Castillo JG, Retamal MA, Yánez A, Morano HJ, Hermosilla JG (1977) Quantitative studies on the soft- bottom macrobenthic animal communities of shallow Antarctic bays. In: Llano GA (ed) Adaptations within Antarctic ecosystems. Proc 3rd SCAR Symp Antarct Biol, Smithsonian Institute, Washington, DC, p 361-387

Gambi M, Buia MC, Mazzella L, Lorenti M, Scipione MB (2000) Spatiotemporal variability in the structure of benthic populations in a physically controlled system off Terra Nova Bay: the shallow hard bottoms. In: Faranda F, Guglielmo L, Ianora A (eds) Ross Sea ecology. SpringerVerlag, Heidelberg, p 527-538

Gonzalez-Cabrera PJ, Dowd F, Pedibhotla VK, Rosario R, Stanley-Samuelson D, Petzel D (1995) Enhanced hypoosmoregulation induced by warm-acclimation in antarctic fish is mediated by increased gill and kidney $\mathrm{Na}+\mathrm{K}(+)-$ ATPase activities. J Exp Biol 198:2279-2291

Gutt J, Starmans A, Dieckmann G (1996) Impact of iceberg scouring on polar benthic habitats. Mar Ecol Prog Ser 137:311-316

Hain S (1990) Die beschalten benthischen Mollusken (Gastropoda und Bivalvia) des Weddellmeeres, Antarktis. Ber Polarforsch 70:1-184 (English abstract)

> Hansen J, Sato M, Ruedy R, Lo K, Lea DW, Medina-Elizade M (2006) Global temperature change. Proc Natl Acad Sci USA 103:14288-14293

Harper EM, Peck LS (2003) Predatory behaviour and metabolic costs in the Antarctic muricid gastropod Trophon longstaffi. Polar Biol 26:208-217

> Heilmayer O, Brey T, Portner HO (2004) Growth efficiency and temperature in scallops: a comparative analysis of species adapted to different temperatures. Funct Ecol 18: 641-647

Held C, Waegele W (2005) Cryptic speciation in the giant Antarctic isopod Glyptonotus antarcticus (Isopoda: Valvifera: Chaetiliidae). Sci Mar 69:175-181

Holeton CL, Florence N, Sanders R, Brown L and others (2005) Physiological state of phytoplankton communities in the Southwest Atlantic sector of the Southern Ocean, as measured by fast repetition rate fluorometry. Polar Biol 29:44-52

Johnston IA, Calvo J, Guderley H, Fernandez D, Palmer L (1998) Latitudinal variation in the abundance and oxidative capacities of muscle mitochondria in perciform fishes. J Exp Biol 201:1-12

Kaiser S, Barnes DKA (2008) Southern Ocean deep-sea biodiversity: sampling strategies and predicting responses to climate change. Clim Res 37:165-179

King JC, Turner J, Marshall GJ, Conolley WM, Lachlan-Cope TA (2003) Antarctic Peninsula climate variability and its causes as revealed by analysis of instrumental records. Antarct Res Ser 79:17-30

Lewis PN, Hewitt CL, Riddle M, McMinn A (2003) Marine introductions in the Southern Ocean: an unrecognised hazard to biodiversity. Mar Pollut Bull 46:213-223

> Linse K, Griffiths HJ, Barnes DKA, Clarke A (2006) Biodiversity and biogeography of Antarctic and sub-Antarctic Mollusca. Deep-Sea Res II 53:985-1008

> Lowe CJ, Davison W (2005) Plasma osmolarity, glucose concentration and erythrocyte responses of two Antarctic nototheniid fishes to acute and chronic thermal change. J Fish Biol 67:752-766

Lynch M, Lande R (1993) Evolution and extinction in response to environmental change. In: Kareiva P, Kingsolver JG, Huey RB (eds) Biotic interactions and global change. Sinauer Associates, Sunderland, MA, p 234-250

> Meredith MP, King JC (2005) Climate change in the ocean to the west of the Antarctic Peninsula during the second half of the 20th century. Geophys Res Lett 32:L19604 
Moore JK, Abbott MR, Richman JG (1999) Location and dynamics of the Antarctic Polar Front from satellite sea surface temperature data. J Geophys Res 104:3059-3073

Munilla T (2008) Check-list of the pycnogonids from Antarctic and subAntarctic waters. Zoogeographic implications. Antarct Sci (in press)

Murphy JM, Mitchell JFB (1995) Transient response of the Hadley Centre coupled ocean-atmosphere model to increasing carbon dioxide. II. Spatial and temporal structure of response. J Clim 8:57-80

Nevo E (1998) Molecular evolution and ecological stress at global, regional and local scales: the Israeli perspective. J Exp Zool 282:95-119

> Orejas C, López-González PJ, Gili JM, Teixidó N, Gutt J, Arntz WE (2002) Distribution and reproductive ecology of the Antarctic octocoral Ainigmaptilon antarcticum in the Weddell Sea. Mar Ecol Prog Ser 231:101-114

Orr JC, Fabry VJ, Aumont O, Bopp L and others (2005) Anthropogenic ocean acidification over the twenty-first century and its impact on calcifying organisms. Nature 437:681-686

Pearse JS (1969) Slow developing demersal embryos and larvae of the Antarctic sea star Odontaster validus. Mar Biol 3:110-116

Pearse JS, McClintock JB, Bosch I (1991) Reproduction in Antarctic benthic marine invertebrates: tempos, modes and timing. Am Zool 31:65-80

Peck LS (1989) Temperature and basal metabolism in two Antarctic marine herbivores. J Exp Mar Biol Ecol 127:1-2

Peck LS (2005) Prospects for surviving climate change in Antarctic aquatic species. Front Zool 2:9

$>$ Peck LS, Bullough LW (1993) Growth and population structure in the infaunal bivalve Yoldia eightsi in relation to iceberg activity at Signy Island, Antarctica. Mar Biol 117:235-241

Peck LS, Webb K, Bailey D (2004) Extreme sensitivity of biological function to temperature in Antarctic marine species. Funct Ecol 18:625-630

Peck LS, Convey P, Barnes DKA (2006) Environmental constraints on life histories in Antarctic ecosystems: tempos, timings and predictability. Biol Rev Camb Philos Soc 81:75-109

Peck LS, Powell DK, Tyler PA (2007a) Very slow development in two Antarctic bivalve molluscs, the infaunal clam, Laternula elliptica and the scallop Adamussium colbecki. Mar Biol 150:1191-1197

Peck LS, Morley SA, Portner HO, Clark MS (2007b) Thermal limits of burrowing capacity are linked to oxygen availability and size in the Antarctic clam Laternula elliptica. Oecologia 154:479-484

Peck LS, Webb KE, Miller A, Clark MS, Hill T (2008) Temperature limits to activity, feeding and metabolism in the Antarctic starfish Odontaster validus. Mar Ecol Prog Ser 358:181-189

Podrabsky JE, Somero GN (2006) Inducible heat tolerance in Antarctic notothenioid fishes. Polar Biol 30:39-43

> Pörtner HO (2002) Physiological basis of temperature-

Submitted: September 18, 2007; Accepted: December 21, 2007 dependent biogeography: trade-offs in muscle design and performance in polar ectotherms. J Exp Biol 205: $2217-2230$

Pörtner HO, Hardewig I, Sartoris FJ, Van Dijk PLM (1998) Energetic aspects of cold adaptation: critical temperatures in metabolic, ionic and acid-base regulation? In: Pörtner HO, Playle RC (eds) Cold ocean physiology. Cambridge University Press, Cambridge, p 88-120

Post AL, Hemer MA, O'Brien PE, Roberts D, Craven M (2007) History of benthic colonization beneath the Amery ice shelf, East Antarctica. Mar Ecol Prog Ser 344:29-37

Poulin E, Palma AT, Feral JP (2002) Evolutionary versus ecological success in Antarctic benthic invertebrates. Trends Ecol Evol 17:218-222

Raupach MR, Marland G, Ciais P, Le Quéré C, Canadell JG, Klepper G, Field CB (2007) Global and regional drivers of accelerating $\mathrm{CO}_{2}$ emissions. Proc Natl Acad Sci USA 104: 10288-10293

Sahade R, Tatian M, Kowalke J, Kuhne S, Esnal GB (1998) Benthic faunal associations on soft substrates at Potter Cove, King George Island, Antarctica. Polar Biol 19:85-91

Seebacher F, Davison W, Lowe CJ, Franklin CE (2005) A falsification of the thermal specialization paradigm: compensation for elevated temperatures in Antarctic fishes. Biol Lett 1:151-154

Smedsrud LH (2005) Warming of the deep water in the Weddell Sea along the Greenwich meridian: 1977-2001. Deep-Sea Res I 52:241-258

Somero GN, DeVries AL (1967) Temperature tolerance of some Antarctic fishes. Science 156:257-258

Southward AJ, Langmead O, Hardman-Mountford NJ, Aitken $\mathrm{J}$ and others (2004) Long-term oceanographic and ecological research in the western English Channel. Adv Mar Biol 47:1-105

Turley CM, Roberts JM, Guinotte JM (2007) Corals in deepwater: Will the unseen hand of ocean acidification destroy cold-water ecosystems? Coral Reefs 26:445-448

> Tyler PA, Reeves S, Peck LS, Clarke A, Powell D (2003) Seasonal variation in the gametogenic ecology of the Antarctic scallop Adamussium colbecki. Polar Biol 26:727-733

> Valentine JW, Jablonski D (1991) Biotic effects of sea-level change: the Pleistocene test. J Geophys Res 96:6873-6878

> Waller C, Barnes DKA, Convey P (2006) Ecological contrasts across an Antarctic land-sea interface. Austral Ecol 31: 656-666

> Walther GR, Post E, Convey P, Menzel A and others (2002) Ecological responses to recent climate change. Nature 416:389-395

Young JS, Peck LS, Matheson T (2006) The effects of temperature on walking and righting in temperate and Antarctic crustaceans. Polar Biology 29:978-987

Zachos J, Pagani M, Sloan L, Thomas E, Billups K (2001) Trends, rhythms and aberrations in global climate $65 \mathrm{Ma}$ to present. Science 292:686-693

Zwally HJ, Comiso JC, Parkinson CL, Cavalieri DJ, Gloersen P (2002) Variability of Antarctic sea ice 1979-1998. J Geophys Res 107:C5,3041

Proofs received from author(s): August 13, 2008 